Article

\title{
Imipramine Inhibits Migration and Invasion in Metastatic Castration-Resistant Prostate Cancer PC-3 Cells via AKT-Mediated NF-KB Signaling Pathway
}

\author{
Eun Yeong Lim ${ }^{1,2}$, Joon Park ${ }^{1,2}$, Yun Tai Kim ${ }^{1,2, * \mathbb{C}}$ and Min Jung Kim ${ }^{3, *}$ \\ 1 Research Group of Functional Food Materials, Korea Food Research Institute, 245, Nongsaengmyeong-ro, \\ Iseo-myeon, Wanju-gun, Jeollabuk-do 55365, Korea; 50005@kfri.re.kr (E.Y.L.); 50029@kfri.re.kr (J.P.) \\ 2 Department of Food Biotechnology, Korea University of Science \& Technology, 217 Gajeong-ro, Yuseong-gu, \\ Daejeon 34113, Korea \\ 3 Research Group of Natural Materials and Metabolism, Korea Food Research Institute, 245, \\ Nongsaengmyeong-ro, Iseo-myeon, Wanju-gun, Jeollabuk-do 55365, Korea \\ * Correspondence: ytkim@kfri.re.kr (Y.T.K.); mjkim14@kfri.re.kr (M.J.K.); Tel.: +82-63-219-9295 (Y.T.K.); \\ +82-63-219-9380 (M.J.K.); Fax: +82-63-219-9876 (Y.T.K. \& M.J.K.)
}

Academic Editors: Helen Osborn, Jean Jacques Vanden Eynde, Annie Mayence and

Tien L. Huang

Received: 18 September 2020; Accepted: 10 October 2020; Published: 11 October 2020

check for updates

\begin{abstract}
Imipramine (IMI) is a tricyclic synthetic antidepressant that is used to treat chronic psychiatric disorders, including depression and neuropathic pain. IMI also has inhibitory effects against various cancer types, including prostate cancer; however, the mechanism of its anticancer activity is not well understood. In the present study, we investigated the antimetastatic and anti-invasive effects of IMI in metastatic castration-resistant prostate cancer PC-3 cells, with an emphasis on the serine/threonine protein kinase AKT-mediated nuclear factor kappa B (NF- $\mathrm{KB}$ ) signaling pathway. While IMI did not induce cell death, it attenuated PC-3 cell proliferation. According to the wound healing assay and invasion assay, migration and invasion in PC-3 cells were significantly inhibited by IMI in a dose-dependent manner. IMI significantly downregulated p-AKT protein expression but upregulated phospho-extracellular signal-regulated kinase (ERK1)/2 protein expression levels. Furthermore, IMI treatment resulted in decreased AKT-mediated downstream signaling, including $\mathrm{p}$-inhibitor of $\kappa B$ kinase $(\mathrm{IKK}) \alpha / \beta$, p-inhibitor of $\kappa \mathrm{B}(\mathrm{I} \kappa \mathrm{B} \alpha)$, and $\mathrm{p}$-p65. Inhibited NF- $K B$ signaling reduced the secretion of several proinflammatory cytokines and chemokine by PC-3 cells. Overall, our study explored the negative correlation between the use of antidepressants and prostate cancer progression, showing that IMI attenuated cell viability, migration, and invasion of PC-3 cells by suppressing the expression of AKT and NF-KB-related signaling proteins and secretion of tumor necrosis factor- $\alpha$ (TNF- $\alpha)$, interleukin-1 $\beta$ (IL-1 $\beta)$, and monocyte chemoattractant protein-1 (MCP-1).
\end{abstract}

Keywords: imipramine; antidepressants; prostate cancer; migration; invasion

\section{Introduction}

Prostate cancer is one of the most common invasive cancers in men, with 1,276,000 cases and 359,000 deaths worldwide in 2018 [1]. In Korea, the incidence of prostate cancer has more than doubled in the last 15 years due to the aging population and the westernization of eating habits [2]. Patients with localized prostate cancer are managed by radiation therapy, surgery, or hormone therapy, while locally advanced prostate cancer and metastatic prostate cancer are mainly treated with androgen-deprivation therapy (ADT) [3]. ADT leads to the remission of prostate cancer in about $90 \%$ of the patients as evidenced by decreased circulating levels of prostate-specific antigen (PSA) [4]. However, continuous 
ADT treatment attenuates the response of metastatic castration-sensitive prostate cancer (mCSPC) to ADT within 12-24 months and causes changes in the types of metastatic prostate cancer from mCSPC to metastatic castration-resistant prostate cancer (mCRPC) [5,6]. mCRPC is associated with a high risk of morbidity and mortality, with a short survival time of only 16-18 months [7]. Therefore, it is urgent to suppress mCRPC and develop new efficient chemotherapeutic agents for the treatment of ADT-resistant mCRPC.

Food and Drug Administration (FDA)-approved chemotherapeutic drugs for mCRPC are mitoxantrone, docetaxel, and cabazitaxel. Mitoxantrone, approved in 1996, had a palliative benefit and decreased PSA levels [8-10]. Subsequently, docetaxel and cabazitaxel, approved in 2004 and 2010 , respectively, replaced mitoxantrone; these drugs relieved symptoms, improved PSA response rate, and led to extended overall survival in mCRPC patients [9,11-13]. However, both of these drugs also have limitations because some patients with mCRPC are not controlled by these drugs, and resistance to treatment eventually occurs. To overcome these disadvantages, researchers are constantly exploring new chemotherapeutic agents.

One of the suggestions that resulted from these efforts is to use antidepressants as new mCRPC inhibitors. Several classes of antidepressants exist, such as nonselective monoamine reuptake inhibitors, selective serotonin reuptake inhibitors, nonselective monoamine oxidase inhibitors, monoamine oxidase A (MAO-A) inhibitors, and other antidepressants including tricyclic antidepressants (TCAs) [14,15]. Among these, MAO-A inhibitors are known for their efficacy and mechanisms of prostate cancer suppression [16,17]. MAO-A inhibitors, including clogyline and mocrobemide, suppressed the activation of Shh-interleukin 6-receptor activator of nuclear factor kappaB ligand (Shh-IL6-RANKL) signaling, further suppressed the metastasis of CRPC cells, and prolonged overall survival in patients in preclinical studies [16]. In addition, antiandrogen enzalutamide-resistant mCRPC cells derived by chronic exposure to enzalutamide could be re-sensitized to enzalutamide by treatment with MAO-A inhibitors such as phenelzine and clorgyline [17]. However, the efficacy and mechanisms of action of TCAs in mCRPC cells have been poorly studied.

Imipramine (IMI, 10,11-dihydro- $N, N$-dimethyl-5H-dibenz $[b, f]$ azepine-5-propanamine hydrochloride) is a member of the TCA family and is used in the treatment of depressive disorders, neuropathic pain, and nocturnal enuresis [18-20]. In addition to these neurologic properties, IMI has exhibited antiproliferative and anticancer activities in various cancer cells such as myeloma, small-cell lung cancer, pancreatic neuroendocrine cancer, and prostate cancer cells [21-23]. However, the mechanism of IMI action in prostate cancer, especially mCRPC, has not been fully studied. The only known mechanisms of IMI action involve the inhibition of the voltage sensitive ether-à-go-go potassium (EAG 1) channel activity in one of the mCRPC cell lines, DU145, reduction of cell proliferation, and induction of apoptosis [23].

Therefore, the aim of this study was to investigate the effects and mechanisms of IMI action during the migration and invasion in PC-3 cells, which can be considered as a cellular model of mCRPC because they are androgen-insensitive and have a high metastatic potential.

\section{Results}

\subsection{IMI Inhibits Proliferation of PC-3 Cells without Causing Cell Death}

The antiproliferative properties of IMI were evaluated by exposing the prostate cancer cell line PC-3 to different concentrations of IMI $\left(3.8 \times 10^{-4}\right.$ to $\left.1.0 \times 10^{2} \mu \mathrm{M}\right)$ for $12 \mathrm{~h}$ and $72 \mathrm{~h}$. IMI treatment resulted in decreased proliferation of PC-3 cells in a dose-dependent and time-dependent manner (Figure 1a). In the IMI-treated group at $12 \mathrm{~h}$, IMI at $<10 \mu \mathrm{M}$ did not affect cell proliferation; however, concentrations above $10 \mu \mathrm{M}$ resulted in decreased cell proliferation in a dose-dependent manner. In the IMI-treated group at $72 \mathrm{~h}$, IMI had a dose-dependent inhibitory effect on cell proliferation over the entire dose range. To confirm cell viability, PC-3 cells were treated with the highest concentration $(100 \mu \mathrm{M})$ of IMI for a longer period $(72 \mathrm{~h})$, and the cell viability was visualized using a LIVE/DEAD 
kit and quantified (Figure 1b,c). Although PC-3 cells were exposed to high doses for a long period, the number of live and dead cells and cell viability in IMI-treated cells did not show significant differences compared to those in the untreated cells. We concluded that IMI did not induce cell death but attenuated the proliferation of PC-3 cells.

(a)
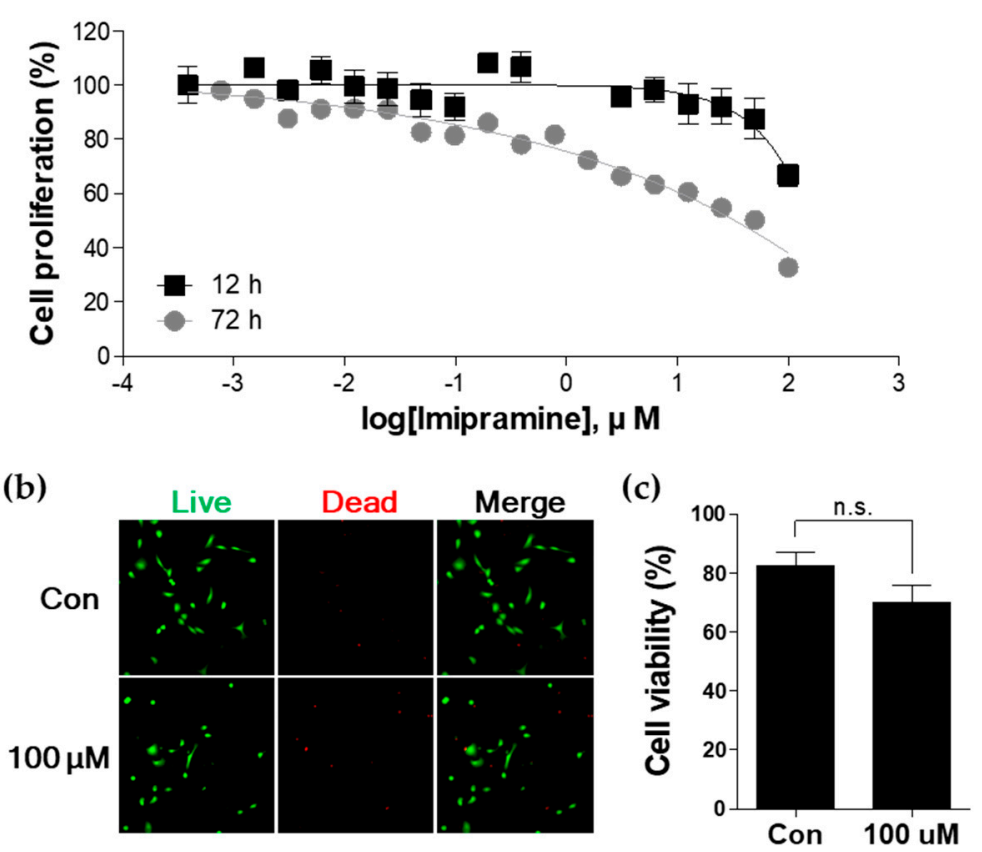

Figure 1. Effect of imipramine treatment on proliferation of PC-3 cells. (a) PC-3 cells were treated with $3.8 \times 10^{-4}$ to $1.0 \times 10^{2} \mu \mathrm{M}$ imipramine (IMI) for $12 \mathrm{~h}$ and $72 \mathrm{~h}$, and cell proliferation was evaluated using a water-soluble tetrazolium salts, WST-1 assay. (b,c) Cell viability at $100 \mu \mathrm{M}$ of imipramine treatment for $72 \mathrm{~h}$ was visualized and quantified using a LIVE/DEAD kit. Green and red fluorescence indicates live and dead cells, respectively. n.s.: not significant.

\subsection{IMI Inhibits PC-3 Cell Migration}

To determine whether IMI inhibits migration in PC-3 cells, wound healing was monitored in PC-3 cells treated with different concentrations of IMI $(6.25,12.5,25,50$, and $100 \mu \mathrm{M})$. As shown in Figure 2b,c, IMI significantly decreased the migration of PC-3 cells in a dose-dependent manner compared to that in the control, untreated cells $(p<0.001)$. These results demonstrated that IMI suppressed migration in PC-3 cells in vitro.

\subsection{IMI Inhibits PC-3 Cell Invasion}

To determine the effect of IMI on cell invasion, PC-3 cells were treated with $12.5,25,50$, and $100 \mu \mathrm{M}$ IMI, after which the cells were allowed to invade in Matrigel-coated Transwells for $24 \mathrm{~h}$. The number of invading cells was significantly reduced by the IMI treatment in a dose-dependent manner (Figure 2c,d). Compared to the untreated group, IMI at 50 and $100 \mu \mathrm{M}$ suppressed cell invasion by $79.8 \%$ and $92.5 \%$, respectively. These data clearly show that IMI is a strong suppressor of PC-3 cell invasion. 
(a)

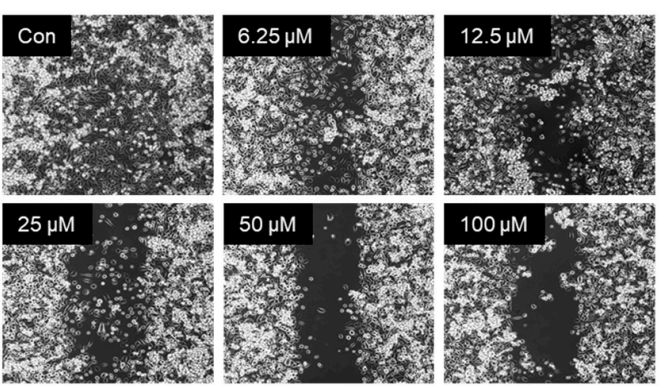

(b)

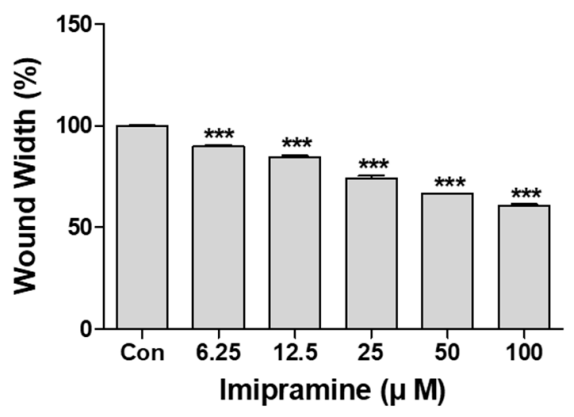

(c)
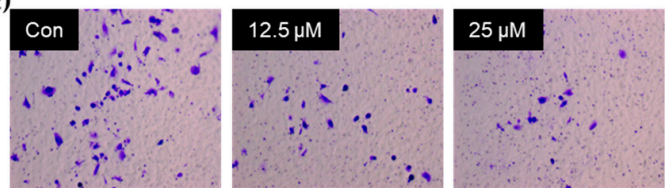

$50 \mu \mathrm{M}$

$100 \mu \mathrm{M}$

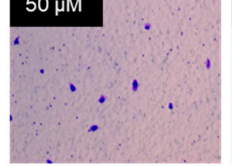

(d)

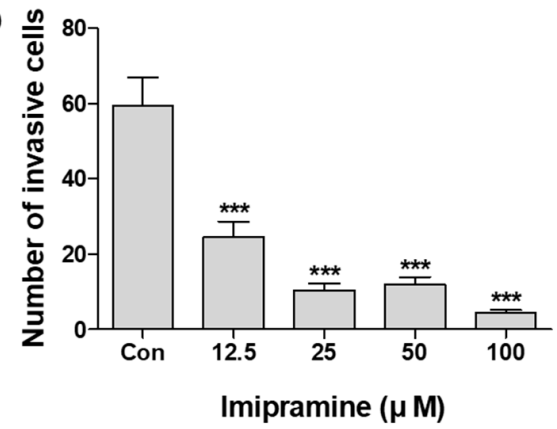

Figure 2. Inhibition of cell migration and invasion by imipramine. (a) PC-3 cells were treated with imipramine $(0-100 \mu \mathrm{M})$ for $12 \mathrm{~h}$. Representative images of the cells treated with the indicated doses were acquired in an optical microscope after the wounding. (b) The percentage of wound recovery was normalized to untreated control cells. (c) PC-3 cells were treated with imipramine $(0-100 \mu \mathrm{M})$ for $12 \mathrm{~h}$ and the effects of imipramine on invasion were analyzed using Matrigel invasion assays. Representative images were taken in the bottom of Transwell filter at indicated time points via phase-contrast microscopy. (d) Quantitative data of an invasion assay were expressed as the number of invasive cells. Data are presented as the mean \pm standard error of the mean (SEM) and analyzed using one-way ANOVA; ${ }^{* * *} p<0.001$ compared with untreated cells.

2.4. IMI Inhibits Phosphorylation of Serine/threonine Protein Kinase (AKT), but Not that of Extracellular Signal-regulated kinase (ERK)1/2 in PC-3 Cells

In order to investigate the mechanism of IMI action, the effects of IMI treatment $(6.25,12.5,25$, 50 , and $100 \mu \mathrm{M})$ on protein expression levels of AKT and ERK1/2 were evaluated using Western blot analysis in PC-3 cells. As shown in Figure 3, activation of AKT in PC-3 cells was significantly suppressed by $\operatorname{IMI}(6.25,12.5,25,50$, and $100 \mu \mathrm{M})$ at 48 and $72 \mathrm{~h}$, as evidenced by the dose-dependent decrease in AKT phosphorylation. However, the expression of phosphorylated ERK1/2 was upregulated by IMI at $48 \mathrm{~h}$ and $72 \mathrm{~h}$.

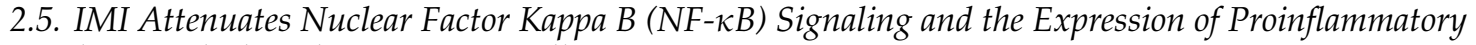 Cytokines and Chemokines in PC-3 Cells}

Cancer proliferation is associated with NF- $\mathrm{kB}$ signaling pathway and inflammatory cytokines. The protein expression levels of p-inhibitor of $\kappa B$ kinase $(\mathrm{IKK}) \alpha / \beta, \mathrm{IKK} \alpha$, p-inhibitor of $\kappa \mathrm{B}(\mathrm{I} \kappa \mathrm{B} \alpha)$, $\mathrm{I} \kappa \mathrm{B} \alpha, \mathrm{p}-\mathrm{p} 65, \mathrm{p} 65$, and $\beta$-actin in the NF- $\mathrm{B}$ signaling pathway, which is downstream to AKT activation, and the secretion of inflammatory cytokines were estimated using Western blotting and RT-PCR, respectively. As a result, IMI inactivated the NF- $\mathrm{BB}$ signaling pathway in PC-3 cells (Figure 4a-e). Phosphorylation of IKK $\alpha / \beta, I \kappa B \alpha$, and p65 was inhibited by IMI. Concurrently, degradation of I $\mathrm{B} \alpha$ was reduced by IMI. In particular, phosphorylated p65 levels were significantly attenuated in response to IMI treatment $(25-100 \mu \mathrm{M})$ in a dose-dependent manner. 
(a)

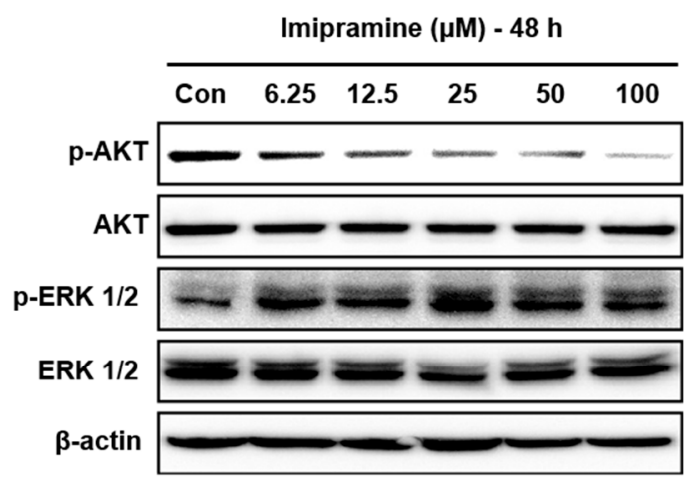

(d)

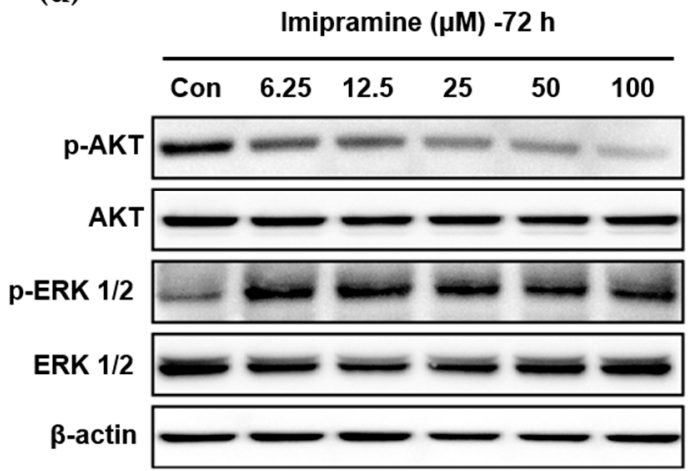

(b)

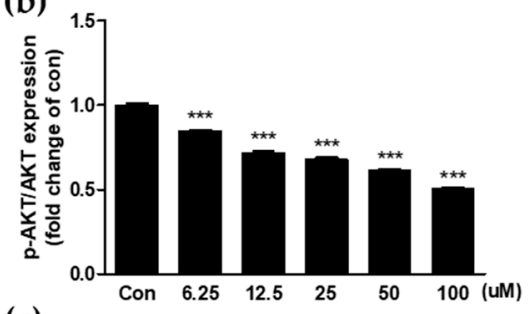

(c)

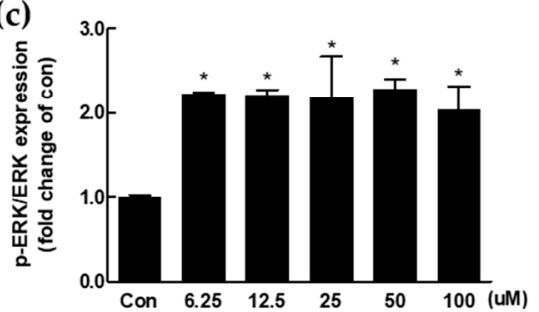

(e)
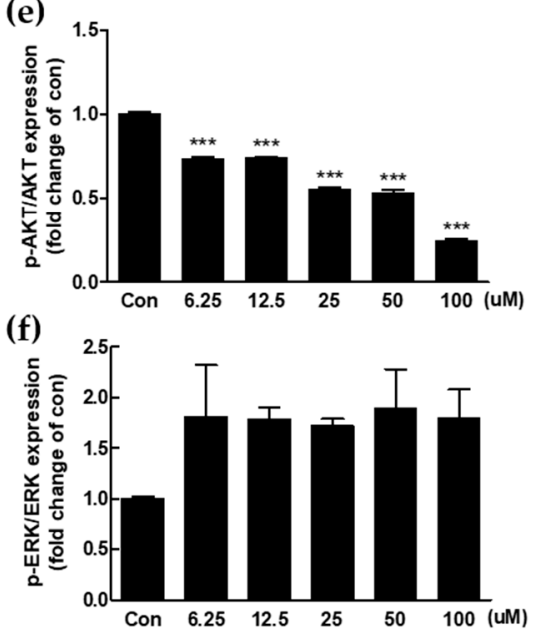

Figure 3. Effect of imipramine on phosphorylation of serine/threonine protein kinase (AKT) and extracellular signal-regulated kinase (ERK)1/2 at $48 \mathrm{~h}$ and $72 \mathrm{~h}$ in PC-3 cells. (a,d) Protein expression of AKT, p-AKT, ERK1/2, p-ERK1/2, and $\beta$-actin in PC-3 cells was detected using Western blotting. $(\mathbf{b}, \mathbf{c}, \mathbf{e}, \mathbf{f})$ Quantitative data of phosphorylated AKT and ERK were normalized to the untreated cells. Data are presented as the mean $\pm \operatorname{SEM}(n=3)$ and analyzed using one-way ANOVA; ${ }^{*} p<0.05$, and ${ }^{* * *} p<0.001$ compared with untreated cells.

Because protein phosphorylation during NF- $\mathrm{kB}$ signaling regulates the expression of inflammatory cytokines, the messenger RNA (mRNA) expression of inflammatory cytokines, including tumor necrosis factor- $\alpha$ (TNF- $\alpha)$, interleukin- $1 \beta$ (IL-1 $\beta)$, and monocyte chemoattractant protein-1 (MCP-1) was quantitatively analyzed using qRT-PCR. The mRNA levels of all three cytokines were significantly suppressed by IMI treatment (Figure $4 \mathrm{f}-\mathrm{h}$ ). The mRNA level of TNF- $\alpha$ was significantly inhibited by $100 \mu \mathrm{M}$. The mRNA levels of $I L-1 \beta$ and $M C P-1$ were significantly attenuated by IMI concentrations ranging from $12.5 \mu \mathrm{M}$ to $100 \mu \mathrm{M}$ and from $25 \mu \mathrm{M}$ to $100 \mu \mathrm{M}$, respectively. 
(a)
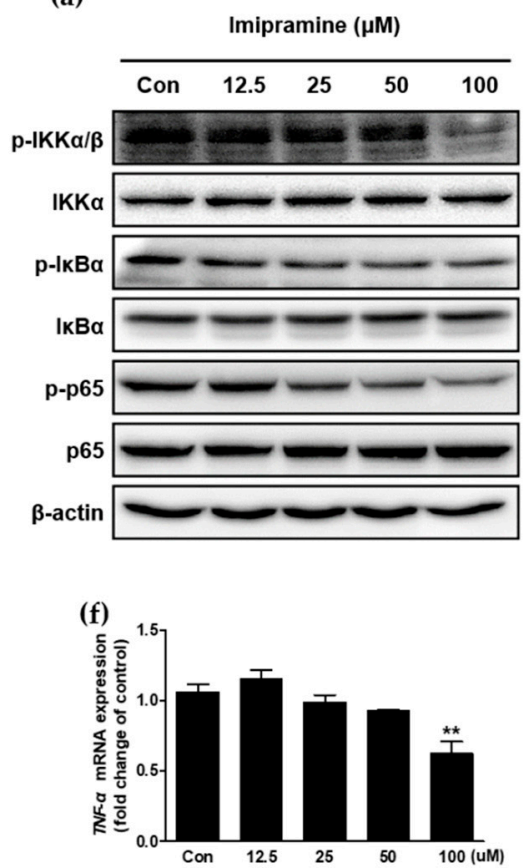

(b)

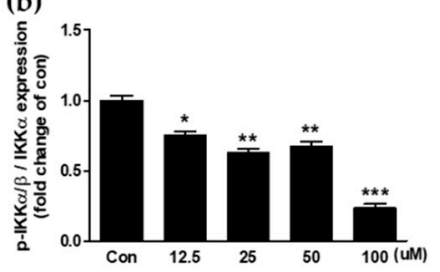

(d)
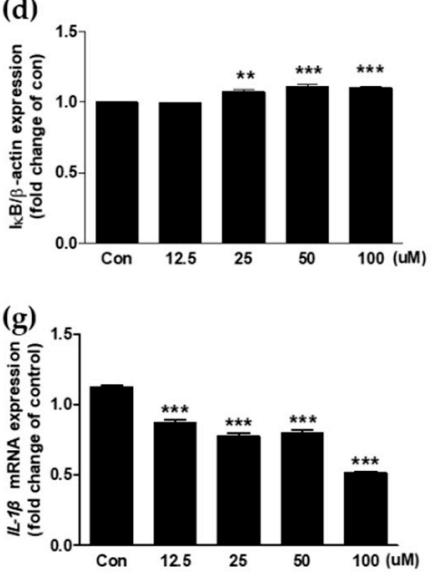

(c)

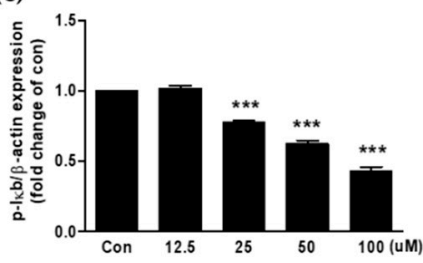

(e)
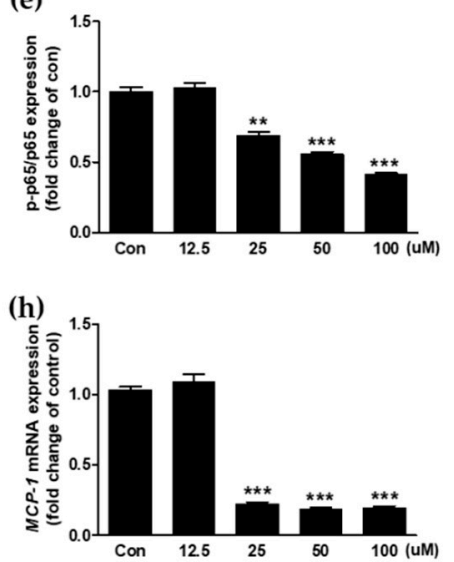

Figure 4. Effect of imipramine on protein phosphorylation during nuclear factor kappa B (NF- $\mathrm{B}$ ) signaling and the expression of inflammatory cytokines at $48 \mathrm{~h}$ in PC-3 cells. (a) Protein expression of $\mathrm{p}$-inhibitor of $\kappa B$ kinase $(\mathrm{IKK}) \alpha / \beta, \mathrm{IKK} \alpha$, p-inhibitor of $\kappa \mathrm{B}(\mathrm{I} \kappa \mathrm{B} \alpha), \mathrm{I} \kappa \mathrm{B} \alpha, \mathrm{p}$-p65, p65, and $\beta$-actin in PC-3 cells was detected using Western blotting. (b) Quantitative data of phosphorylated IKK $\alpha / \beta$ were normalized to the untreated cells. (c) Quantitative data of phosphorylated I $\mathrm{k} \alpha$ were normalized to the untreated cells. (d) Quantitative data of IкB $\alpha$ were normalized to the untreated cells. (e) Quantitative data of phosphorylated p65 were normalized to the untreated cells. (f-h) The production of tumor necrosis factor- $\alpha(T N F-\alpha)$, interleukin-1 $\beta(I L-1 \beta)$, and monocyte chemoattractant protein-1 (MCP-1) messenger RNA (mRNA) was analyzed using quantitative real-time RT-PCR. Data are presented as the mean \pm SEM of three independent experiments and analyzed using one-way ANOVA; $p<0.05$, ** $p<0.01$, and ${ }^{* * *} p<0.001$ compared with untreated cells.

\section{Discussion}

This is the first study to demonstrate that IMI attenuates cell proliferation, migration, and invasion of PC-3 cells via inactivation of AKT-mediated NF- $\mathrm{BB}$ signaling and activation of ERK-mediated signaling. IMI suppressed the phosphorylation of AKT, IKK $\alpha / \beta, I \kappa B \alpha$, and p65 in PC-3 cells in a concentration-dependent manner. Downregulated AKT-mediated NF- $\mathrm{kB}$ signaling was associated with decreased gene expression levels of cytokines including TNF- $\alpha, I L-1 \beta$, and $M C P-1$. Our findings suggest that imipramine could be a potential candidate for treatment of prostate cancers.

A number of signaling pathways regulate cellular metabolism and cancer progression. The representative mechanisms involved in cell survival, growth, proliferation, migration, and invasion in tumors and tumor cell lines include the phosphatidylinositol 3-kinase (PI3K)/AKT pathway and mitogen-activated protein kinase (MAPK)/extracellular signal-regulated kinase (ERK) pathway. These pathways are also important for mCRPC progression. PI3K activation stimulates downstream phosphatidylinositol $(3,4,5)$-trisphosphate (PIP3) production and further phosphorylation of AKT (Ser473 and Thr308) in the PI3K/AKT pathway [24]. PI3K inactivation by PI3K inhibitor (LY294002) attenuated the protein expression of PI3K (p85) and p-AKT (Ser473) and further suppressed PC-3 cell invasion [25]. Selective inhibition of the PI3K/AKT pathway with the AKT inhibitor, AZD5363, also retards cellular proliferation and tumor progression in CRPC xenografts [26]. In particular, AKT is an attractive therapeutic target to inhibit $\mathrm{MCRPC}$ progression because of the following characteristics of PC-3 cells: (1) excessive AKT level, (2) loss of phosphatase and tensin homolog (PTEN), and (3) 
AKT-induced inhibition of Raf/mitogen-activated protein kinase kinase (MEK)/ERK signaling cascades. According to phospho-proteomic analysis in metastatic tumor samples, mCRPC contains excessive amounts of AKT protein as the most common tyrosine kinase [27]. PTEN, a tumor suppressor gene that is negatively involved in AKT phosphorylation by PI3K, is lost in $~ 50 \%$ of tumor tissue in mCRPC patients and is known to inhibit cell proliferation and migration in prostate cancer [28,29]. Both excessive AKT accumulation and loss of PTEN accelerate prostate carcinogenesis. Raf/MEK/ERK signaling cascades are upregulated not only by Ras activation but also by AKT inhibition in several types of cancers, such as prostate and breast cancers [30,31]. ERK signaling has two opposing roles: one is associated with cell proliferation, migration, and invasion [32], and the other one is relevant to the proapoptotic action of chemotherapeutics. Various antitumor agents, including resveratrol, betulinic acid, apigenin, and ororidonin, trigger cancer cell death through ERK activation [33-36]. This is consistent with other chemotherapeutic agents in which phenethyl isothiocyanate activates MAPK/ERK signaling cascades and induces apoptosis in PC-3 cells [37]. In addition, upregulated MAPK/ERK signaling by AKT inactivation also induced loss of differentiation of PC-3 cells [38]. IMI inhibited AKT phosphorylation, increased ERK activation in PC-3 cells, and attenuated cell proliferation, instead of inducing cell death.

CRPC contains higher levels of AKT and NF- $\kappa B$ than CSPC and other cancers. The NF- $\kappa B$ family of proteins plays a pleiotropic role in controlling multiple cell functions such as proliferation, survival, cell death, invasion, and angiogenesis; however, this protein family plays a dichotomous role. The canonical NF- $\mathrm{B}$ signaling pathway is executed through the activation of the IKK complex composed of the catalytic subunits (IKK $\alpha$ and IKK $\beta$ ) and the regulatory subunit (IKK $\gamma / \mathrm{NF}-\mathrm{KB}$ essential modifier, NEMO) [39]. Phosphorylated IKK activates $I \kappa B \alpha$ proteins and then phosphorylates $I \kappa B \alpha$ to release the $\mathrm{p} 65($ RelA)/p50(NF-kB1) complex, followed by degradation of $\mathrm{I} \kappa \mathrm{B} \alpha$ by proteasome. The separated $\mathrm{p} 65 / \mathrm{p} 50$ complex is translocated into the nucleus to activate gene transcription. Among NF- $\mathrm{kB}$ family proteins, not NF- $\mathrm{BB} / \mathrm{p} 50$ but NF- $\mathrm{kB} / \mathrm{p} 65$ is constitutively activated in human prostate adenocarcinoma. The NF- $\kappa B$ signaling pathway can be activated by AKT. Several studies have suggested that AKT/NF- $\kappa B$ signaling works together in prostate cancer cells $[40,41]$. The migration and invasion enhancer 1 (MIEN1) gene, which is highly expressed in prostate cancer cells, regulates AKT/NF- $\mathrm{B}$ signaling. Phosphorylation of AKT stimulates mechanistic target of rapamycin complex 1 (mTORC1) and the IKK/NF- $K B$ signaling cascade in PC-3 cells. Consistent with these cascades, inactivated AKT by IMI significantly attenuated the expression levels of phosphorylated IKK $\alpha / \beta, \operatorname{I} \kappa \mathrm{B} \alpha$, and p65 in a dose-dependent manner in PC-3 cells. p65, binding to a consensus DNA sequence in the promoter region, regulates cancer metastasis [42]. Previous studies reported that blocking the p65 attenuated metastasis in prostate cancer; on the other hand, activation of p65 promoted invasion and migration of prostate cancer cells [43-46]. Moreover, suppressed AKT/NF-kB signaling by IMI affected downstream signaling cascades.

Proinflammatory cytokines and chemokines are regulated by NF-kB. Phosphorylation of p65 facilitates its binding to a specific DNA sequence, which triggers the transcriptional activation of NF-кB-regulated genes, including proinflammatory cytokine genes and chemokine genes. We found that IMI-induced deactivation of p65 also attenuated the expression levels of downstream genes, including two proinflammatory cytokine genes (TNF- $\alpha$ and $I L-1 \beta)$ and one chemokine gene (MCP-1). Prostate cancer cells express chemokine and chemokine receptors, as well as endogenously produced chemokines and cytokines such as MCP-1, TNF- $\alpha, I L-1 \beta$, IL-6, and IL-8 [47-49], some of which are secreted at a higher level in PC-3 cells (mCRPC cell line) than in LNCaP cells (mCSPC cell line). MCP-1, a member of the CC chemokine superfamily, is associated with recruitment and activation of monocytes during acute inflammation. Endogenous $M C P-1$, eliciting both autocrine and paracrine responses, promotes cell growth and invasion in prostate cancer cells including primary prostate epithelia (PrEC), LNCaP, C4-2B, and PC-3 cells [50]. TNF- $\alpha$ and $I L-1 \beta$, the major proinflammatory cytokines associated with systemic inflammation, play a critical role in tumorigenesis, tumor progression, and carcinogenesis. Both cytokines also act as autocrine factors; thus, the secretion of endogenously produced TNF- $\alpha$ 
and $I L-1 \beta$ promotes cell proliferation and migration in PC-3 cells. In particular, it is proof that the expression of $I L-1 \beta$ is stimulated by p65 phosphorylation. Finally, IMI-induced suppression of the expression of $T N F-\alpha, I L-1 \beta$, and $M C P-1$ may regulate autocrine signaling and inhibit cell proliferation, migration, and invasion.

In this study, we found that imipramine inhibits proliferation, migration, and invasion in a cellular model of mCRPC, which is expected to be related to AKT/NF- $\mathrm{KB}$ signaling. Some research suggested that upstream AKT signaling including PI3K, PDK1, and PTEN can be binding targets of imipramine [51], but further study will be needed to know the exact target of imipramine. In addition, it is necessary to observe the suppressive effect of imipramine on metastasis using a xenographic tumor model so that the results of in vitro studies can be confirmed in vivo.

\section{Materials and Methods}

\subsection{Materials}

IMI was purchased from Sigma-Aldrich (St. Louis, MO, USA). The antibody against $\beta$-actin was purchased from Santa Cruz Biotech (Santa Cruz, CA, USA). Antibodies against p-IKK $\alpha / \beta, \mathrm{IKK} \alpha, \mathrm{p}-\mathrm{I} \kappa \mathrm{B}$, IKB, p-p65, p65, ERK1/2, p-ERK1/2 (Thr202/Tyr204), AKT, and p-AKT (Ser473) were purchased from Cell Signaling Technology (Beverly, MA, USA).

\subsection{Cell Culture}

The prostate cancer cell line PC-3 was obtained from the Korean Cell Line Bank (KCLB, Seoul, Korea) and cultured in Roswell Park Memorial Institute (RPMI) 1640 (Gibco, Grand Island, NY, USA) containing $10 \%$ fetal bovine serum (FBS; Gibco) and $100 \mathrm{U} / \mathrm{mL}$ penicillin/streptomycin (Gibco) at $37^{\circ} \mathrm{C}$ and $5 \% \mathrm{CO}_{2}$.

\subsection{Cell Proliferation Assay}

PC-3 cells were seeded in 96-well plates $\left(1 \times 10^{3}\right.$ cells/well $)$ and cultured overnight to allow cell adhesion. PC-3 cells were treated with $0.1 \%$ dimethyl sulfoxide (DMSO) or various concentrations of IMI (range: $3.8 \times 10^{-4}$ to $1.0 \times 10^{2} \mu \mathrm{M}$ ) for $12 \mathrm{~h}$ or $72 \mathrm{~h}$. Subsequently, $10 \mu \mathrm{L}$ of water-soluble tetrazolium salts, WST-1 reagent (Roche Diagnostics GmbH, Mannheim, Germany) was added to each well and incubated for $4 \mathrm{~h}$ at $37^{\circ} \mathrm{C}$ in a humidified $5 \% \mathrm{CO}_{2}$ atmosphere. Finally, the absorbance at 450 and $650 \mathrm{~nm}$ was measured using a SpectraMax Plus Plate Reader (Molecular Devices, Sunnyvale, CA, USA). PC-3 cells treated with $0.1 \%$ DMSO served as a control. The percentage of cell proliferation was calculated using the following equation:

Cell proliferation $=\left(\mathrm{OD}_{450}-\mathrm{OD}_{650}\right.$ of IMI-treated cells $) /\left(\mathrm{OD}_{450}-\mathrm{OD}_{650}\right.$ of control $) \times 100$.

\subsection{Live/Dead Cell Viability Assay}

Cell viability was confirmed using a LIVE/DEAD ${ }^{\circledR}$ Cell Imaging Kit (Invitrogen, Waltham, MA, USA). PC-3 cells plated at a density of $1 \times 10^{3}$ cells per well in a 96-well plate were treated with $0.1 \%$ DMSO or $100 \mu \mathrm{M}$ IMI. After $72 \mathrm{~h}$, calcein-AM (live, green) and propidium iodide (PI; dead, red) were added to the cells and incubated for $15 \mathrm{~min}$ at room temperature in the dark. Images of live and dead cells were acquired using a fluorescence microscope (Axio Observer A1; Carl Zeiss AG, Oberkochen, Germany). The percentage of cell viability was calculated according to the following formula:

$\%$ of cell viability $=($ the number of viable cells/the total number of cells $) \times 100$.

\subsection{Wound Healing Assay}

PC-3 cells were seeded at a density of $7 \times 10^{5}$ cells/mL into the two wells of a culture insert (Ibidi $\mathrm{GmbH}$, Martinsried, Germany). After the overnight incubation, cells were grown to full confluence, 
and the culture inserts were removed to make the wound gap. Cells were washed with phosphate buffered saline (PBS) and incubated with five different concentrations of IMI (0-100 $\mu \mathrm{M})$ for $12 \mathrm{~h}$. Representative images for each concentration were captured at 10× magnification using a digital camera attached to an inverted microscope to quantify the relative migration of cells (Axio Observer A1). The area of the wound was quantitatively analyzed using MetaMorph software (Molecular Devices, Sunnyvale, CA, USA), and the percentage of wound recovery was evaluated. Coverage in untreated PC-3 cells was defined as $100 \%$.

\subsection{Cell Invasion Assay}

The cell invasion assay was performed using 24-well Transwell chambers with polycarbonate filters with $8 \mu \mathrm{m}$ pore size (Corning Costar, Corning, New York, NY, USA). Transwell chambers were coated with gelatin solution $(0.1 \%)$ on the lower surface and Matrigel on the upper surface for $30 \mathrm{~min}$. PC-3 cells were seeded at a density of $2 \times 10^{4}$ cells $/ \mathrm{mL}$ in serum-free medium onto the upper compartment of the Transwell, and the lower chambers were filled with medium containing $10 \%$ FBS and various concentrations of IMI $(12.5,25,50$, and $100 \mu \mathrm{M})$. After $24 \mathrm{~h}$, the noninvaded cells and the Matrigel on the upper chamber were gently removed using a cotton-tipped swab; then, cells at the undersurface of the filters were stained with crystal violet stain solution for $20 \mathrm{~min}$ and rinsed several times in distilled water. The number of invaded cells was quantified by visual counting after being photographed using an inverted microscope at 10× magnification.

\subsection{Western Blot Analysis}

PC-3 cells $\left(4 \times 10^{5}\right.$ cells/dish) were seeded in $100 \mathrm{~mm}$ dishes for $24 \mathrm{~h}$ and starved with $0.05 \%$ FBS overnight. PC-3 cells were incubated with five different concentrations of IMI $(3.25,12.5,25,50$, and $100 \mu \mathrm{M}$ ) for $48 \mathrm{~h}$ or $72 \mathrm{~h}$. After the treatment, the cells were lysed using cell lysis buffer (Cell Signaling Technology, Beverly, MA, USA) containing a protease inhibitor cocktail from Roche and phosphatase inhibitor (Sigma Aldrich) for $30 \mathrm{~min}$ on ice. After centrifugation, a bicinchoninic acid (BCA) protein assay kit (Thermo Scientific, Rockford, IL, USA) was used to determine the protein concentration. Equal amounts of protein lysate were separated in 10\% sodium dodecyl sulfate (SDS) polyacrylamide gels and transferred to a polyvinylidene difluoride (PVDF) membrane (Bio-Rad Inc., Hercules, CA, USA). The membrane was blocked with 5\% skim milk in Tris-buffered saline with $0.1 \%$ Tween-20 (TBST) for $1 \mathrm{~h}$ at room temperature and then incubated with the specific primary antibodies, including AKT, phospho-AKT (Ser473), ERK1/2, phospho-ERK1/2 (Thr202/Tyr204), phospho-IKK $\alpha / \beta$, IKK $\alpha$, phospho-IкB, IкB, phospho-p65, and p65, overnight at $4{ }^{\circ} \mathrm{C}$. The membranes were washed in TBST three times and incubated with horseradish peroxidase (HRP)-conjugated secondary antibody at room temperature for $2 \mathrm{~h}$. Protein bands were visualized using a chemiluminescence detection kit (ATTO, Tokyo, Japan). Beta-actin was used as the loading control.

\subsection{Total RNA Isolation and Quantitative Reverse-Transcription Polymerase Chain Reaction (RT-qPCR)}

Total RNA was isolated using the NucleoPin ${ }^{\circledR}$ RNA Plus XS Kit (Macherey-Nagel, Bethlehem, PA, USA) according to the manufacturer's instructions. Reverse transcription of RNA was performed using the ReverTra Ace ${ }^{\circledR}$ qPCR RT Master Mix (Toyobo, Osaka, Japan). First-strand complementary DNA (cDNA) was prepared using $1 \mu \mathrm{g}$ of total RNA. The real-time PCR reaction was performed in a volume of $20 \mu \mathrm{L}$ containing $0.1 \mu \mathrm{g}$ of cDNA, $1 \mu \mathrm{M}$ of each primer (Table 1 ), and Power SYBR ${ }^{\circledR}$ Green PCR Master Mix (Applied Biosystems, Carlsbad, CA, USA). Thermal cycling was carried out in a StepOnePlus Real-Time PCR system (Applied Biosystems, Carlsbad, CA, USA) with a program of $95{ }^{\circ} \mathrm{C}$ for $5 \mathrm{~min}$, followed by 40 cycles of denaturation at $95{ }^{\circ} \mathrm{C}$ for $5 \mathrm{~s}$ annealing, and elongation at $60^{\circ} \mathrm{C}$ for $10 \mathrm{~s}$. Gene expression levels were normalized to the expression level of the housekeeping gene glyceraldehyde-3-phosphate dehydrogenase (GAPDH). Relative gene expression changes, calculated using the $2^{-\Delta \Delta C T}$ method, were reported as number-fold changes compared to those in the control samples. 
Table 1. Primer sequences for RT-qPCR.

\begin{tabular}{cccc}
\hline \multirow{2}{*}{ Species } & Gene & \multicolumn{2}{c}{ Primer Sequence } \\
\cline { 3 - 4 } & & Forward & Reverse \\
\hline \multirow{4}{*}{ Human } & $T N F-\alpha$ & CCTCTCTCTAATCAGCCCTCTG & GAGGACCTGGGAGTAGATGAG \\
& $I L-1 \beta$ & ATGATGGCTTATTACAGTGGCAA & GTCGGAGATTCGTAGCTGGA \\
& $M C P-1$ & CAGCCAGATGCAATCAATGCC & TGGAATCCTGAACCCACTTCT \\
& GAPDH & GGAGCGAGATCCCTCCAAAAT & GGCTGTTGTCATACTTCTCATGG \\
\hline
\end{tabular}

\subsection{Statistics}

All experiments were independently performed at least three times and the values were expressed as the mean \pm standard error of the mean (SEM). Statistical analysis was performed using GraphPad Prism version 5 (GraphPad Software, Inc., La Jolla, CA, USA). Statistical significance was evaluated by unpaired $t$-test for comparison between two groups and one-way ANOVA followed by Dunnett's post hoc test for multiple groups. A $p$-value $<0.05$ was considered to indicate statistically significant difference.

\section{Conclusions}

In conclusion, our results demonstrated that IMI treatment inhibited cell proliferation, migration, and invasion in mCRPC PC-3 cells. The suggested mechanisms of IMI in PC-3 cells include the modulation of AKT/ERK signaling and suppression of the AKT/NF- $\mathrm{kB}$ signaling pathway by preventing I $\mathrm{B} \alpha$ degradation, blocking p 65 phosphorylation, and regulating chemokine and cytokine production. We suggest that IMI may be a potential chemotherapeutic candidate against metastatic CRPC.

Author Contributions: Formal analysis, E.Y.L. and J.P.; investigation, E.Y.L. and J.P.; methodology, E.Y.L.; writing-original draft, E.Y.L. and J.P.; funding acquisition, Y.T.K.; resources, Y.T.K.; supervision, Y.T.K.; writing-reviewing and editing, Y.T.K. and M.J.K.; conceptualization, M.J.K.; project administration, M.J.K. All authors have read and agree to the published version of the manuscript.

Funding: This research was supported by the Main Research Program [E0164502-05] of the Korea Food Research Institute (KFRI).

Conflicts of Interest: The authors declare no conflict of interest.

\section{References}

1. Bray, F.; Ferlay, J.; Soerjomataram, I.; Siegel, R.L.; Torre, L.A.; Jemal, A. Global cancer statistics 2018: GLOBOCAN estimates of incidence and mortality worldwide for 36 cancers in 185 countries. CA Cancer J. Clin. 2018, 68, 394-424. [CrossRef] [PubMed]

2. Jung, K.-W.; Won, Y.-J.; Hong, S.; Kong, H.-J.; Lee, E.S. Prediction of Cancer Incidence and Mortality in Korea. Cancer Res. Treat. J. Korean Cancer Assoc. 2020, 52, 351. [CrossRef] [PubMed]

3. Huggins, C. Prostatic cancer treated by orchiectomy: The five year results. J. Am. Med. Assoc. 1946, 131, 576-581. [CrossRef] [PubMed]

4. Denis, L.; Murphy, G. Overview of phase III trials on combined androgen treatment in patients with metastatic prostate cancer. Cancer 1993, 72, 3888-3895. [CrossRef]

5. Harris, W.P.; Mostaghel, E.A.; Nelson, P.S.; Montgomery, B. Androgen deprivation therapy: Progress in understanding mechanisms of resistance and optimizing androgen depletion. Nat. Clin. Pract. Urol. 2009, 6, 76-85. [CrossRef]

6. Seitz, A.K.; Rauscher, I.; Haller, B.; Krönke, M.; Luther, S.; Heck, M.M.; Horn, T.; Gschwend, J.E.; Schwaiger, M.; Eiber, M. Preliminary results on response assessment using 68 Ga-HBED-CC-PSMA PET/CT in patients with metastatic prostate cancer undergoing docetaxel chemotherapy. Eur. J. Nucl. Med. Mol. Imaging 2018, 45, 602-612. [CrossRef]

7. Marques, R.B.; Dits, N.F.; Erkens-Schulze, S.; Van Weerden, W.M.; Jenster, G. Bypass mechanisms of the androgen receptor pathway in therapy-resistant prostate cancer cell models. PLoS ONE 2010, 5, e13500. [CrossRef] 
8. Tannock, I.F.; Osoba, D.; Stockler, M.R.; Ernst, D.S.; Neville, A.J.; Moore, M.J.; Armitage, G.R.; Wilson, J.J.; Venner, P.M.; Coppin, C. Chemotherapy with mitoxantrone plus prednisone or prednisone alone for symptomatic hormone-resistant prostate cancer: A Canadian randomized trial with palliative end points. J. Clin. Oncol. 1996, 14, 1756-1764. [CrossRef]

9. D'Amico, A.V. US Food and Drug Administration approval of drugs for the treatment of prostate cancer: A new era has begun. J. Clin. Oncol. 2014, 32, 362-364. [CrossRef]

10. Figg, W.D.; Chau, C.H.; Small, E.J. Drug Management of Prostate Cancer; Springer: Berlin/Heidelberg, Germany, 2010.

11. Tannock, I.F.; De Wit, R.; Berry, W.R.; Horti, J.; Pluzanska, A.; Chi, K.N.; Oudard, S.; Théodore, C.; James, N.D.; Turesson, I. Docetaxel plus prednisone or mitoxantrone plus prednisone for advanced prostate cancer. N. Engl. J. Med. 2004, 351, 1502-1512. [CrossRef]

12. Petrylak, D.P.; Tangen, C.M.; Hussain, M.H.; Lara, P.N., Jr.; Jones, J.A.; Taplin, M.E.; Burch, P.A.; Berry, D.; Moinpour, C.; Kohli, M. Docetaxel and estramustine compared with mitoxantrone and prednisone for advanced refractory prostate cancer. N. Engl. J. Med. 2004, 351, 1513-1520. [CrossRef] [PubMed]

13. De Bono, J.S.; Oudard, S.; Ozguroglu, M.; Hansen, S.; Machiels, J.-P.; Kocak, I.; Gravis, G.; Bodrogi, I.; Mackenzie, M.J.; Shen, L. Prednisone plus cabazitaxel or mitoxantrone for metastatic castration-resistant prostate cancer progressing after docetaxel treatment: A randomised open-label trial. Lancet 2010, 376, 1147-1154. [CrossRef]

14. Wang, S.-M.; Han, C.; Bahk, W.-M.; Lee, S.-J.; Patkar, A.A.; Masand, P.S.; Pae, C.-U. Addressing the side effects of contemporary antidepressant drugs: A comprehensive review. Chonnam. Med. J. 2018, 54, 101-112. [CrossRef] [PubMed]

15. World Health Organization. Guidelines for ATC Classification and DDD Assignment 2020; Norwegian Institute of Public Health: Oslo, Norway, 2019.

16. Wu, J.B.; Yin, L.; Shi, C.; Li, Q.; Duan, P.; Huang, J.-M.; Liu, C.; Wang, F.; Lewis, M.; Wang, Y. MAOA-dependent activation of Shh-IL6-RANKL signaling network promotes prostate cancer metastasis by engaging tumor-stromal cell interactions. Cancer Cell 2017, 31, 368-382. [CrossRef] [PubMed]

17. Wang, K.; Luo, J.; Yeh, S.; You, B.; Meng, J.; Chang, P.; Niu, Y.; Li, G.; Lu, C.; Zhu, Y. The MAO inhibitors phenelzine and clorgyline revert enzalutamide resistance in castration resistant prostate cancer. Nat. Commun. 2020, 11, 1-14. [CrossRef] [PubMed]

18. Kocsis, J.H.; Frances, A.J.; Voss, C.; Mann, J.J.; Mason, B.J.; Sweeney, J. Imipramine treatment for chronic depression. Arch. Gen. Psychiatry 1988, 45, 253-257. [CrossRef] [PubMed]

19. Sindrup, S.H.; Holbech, J.V.; Bach, F.W.; Finnerup, N.B.; Brøsen, K.; Jensen, T.S. The impact of serum drug concentration on the efficacy of imipramine, pregabalin, and their combination in painful polyneuropathy. Clin. J. Pain 2017, 33, 1047-1052. [CrossRef]

20. Fritz, G.K.; Rockney, R.M.; Yeung, A.S. Plasma levels and efficacy of imipramine treatment for enuresis. J. Am. Acad. Child Adolesc. Psychiatry 1994, 33, 60-64. [CrossRef]

21. Biber, A.; Durusu, İ.Z.; Özen, C. In vitro anticancer effect of tricyclic antidepressant nortriptyline on multiple myeloma. Turk. J. Biol. 2018, 42, 414-421. [CrossRef]

22. Jahchan, N.S.; Dudley, J.T.; Mazur, P.K.; Flores, N.; Yang, D.; Palmerton, A.; Zmoos, A.-F.; Vaka, D.; Tran, K.Q.; Zhou, M. A drug repositioning approach identifies tricyclic antidepressants as inhibitors of small cell lung cancer and other neuroendocrine tumors. Cancer Discov. 2013, 3, 1364-1377. [CrossRef]

23. Barlaz Us, S.; Sogut, F.; Yildirim, M.; Yetkin, D.; Yalin, S.; Yilmaz, S.N.; Comelekoglu, U. Effect of Imipramine on radiosensitivity of Prostate Cancer: An In Vitro Study. Cancer Investig. 2019, 37, 489-500. [CrossRef] [PubMed]

24. Bai, D.; Ueno, L.; Vogt, P.K. Akt-mediated regulation of NFkB and the essentialness of NFkB for the oncogenicity of PI3K and Akt. Int. J. Cancer 2009, 125, 2863-2870. [CrossRef] [PubMed]

25. Shukla, S.; MacLennan, G.T.; Hartman, D.J.; Fu, P.; Resnick, M.I.; Gupta, S. Activation of PI3K-Akt signaling pathway promotes prostate cancer cell invasion. Int. J. Cancer 2007, 121, 1424-1432. [CrossRef] [PubMed]

26. Thomas, C.; Lamoureux, F.; Crafter, C.; Davies, B.R.; Beraldi, E.; Fazli, L.; Kim, S.; Thaper, D.; Gleave, M.E.; Zoubeidi, A. Synergistic targeting of PI3K/AKT pathway and androgen receptor axis significantly delays castration-resistant prostate cancer progression in vivo. Mol. Cancer Ther. 2013, 12, 2342-2355. [CrossRef] [PubMed] 
27. Drake, J.M.; Graham, N.A.; Lee, J.K.; Stoyanova, T.; Faltermeier, C.M.; Sud, S.; Titz, B.; Huang, J.; Pienta, K.J.; Graeber, T.G. Metastatic castration-resistant prostate cancer reveals intrapatient similarity and interpatient heterogeneity of therapeutic kinase targets. Proc. Natl. Acad. Sci. USA 2013, 110, E4762-E4769. [CrossRef]

28. Ferraldeschi, R.; Rodrigues, D.N.; Riisnaes, R.; Miranda, S.; Figueiredo, I.; Rescigno, P.; Ravi, P.; Pezaro, C.; Omlin, A.; Lorente, D. PTEN protein loss and clinical outcome from castration-resistant prostate cancer treated with abiraterone acetate. Eur. Urol. 2015, 67, 795-802. [CrossRef]

29. Kimbrough-Allah, M.N.; Millena, A.C.; Khan, S.A. Differential role of PTEN in transforming growth factor $\beta$ (TGF- $\beta$ ) effects on proliferation and migration in prostate cancer cells. Prostate 2018, 78, 377-389. [CrossRef]

30. Robertson, B.W.; Bonsal, L.; Chellaiah, M.A. Regulation of Erk1/2 activation by osteopontin in PC3 human prostate cancer cells. Mol. Cancer 2010, 9, 260. [CrossRef]

31. Serra, V.; Scaltriti, M.; Prudkin, L.; Eichhorn, P.J.; Ibrahim, Y.H.; Chandarlapaty, S.; Markman, B.; Rodriguez, O.; Guzman, M.; Rodriguez, S. PI3K inhibition results in enhanced HER signaling and acquired ERK dependency in HER2-overexpressing breast cancer. Oncogene 2011, 30, 2547-2557. [CrossRef]

32. Sun, Y.; Liu, W.-Z.; Liu, T.; Feng, X.; Yang, N.; Zhou, H.-F. Signaling pathway of MAPK/ERK in cell proliferation, differentiation, migration, senescence and apoptosis. J. Recept. Signal Transduct. 2015, 35, 600-604. [CrossRef]

33. Shih, A.; Davis, F.B.; Lin, H.-Y.; Davis, P.J. Resveratrol induces apoptosis in thyroid cancer cell lines via a MAPK-and p53-dependent mechanism. J. Clin. Endocrinol. Metab. 2002, 87, 1223-1232. [CrossRef] [PubMed]

34. Rieber, M.; Rieber, M.S. Signalling responses linked to betulinic acid-induced apoptosis are antagonized by MEK inhibitor U0126 in adherent or 3D spheroid melanoma irrespective of p53 status. Int. J. Cancer 2006, 118, 1135-1143. [CrossRef] [PubMed]

35. Llorens, F.; Miró, F.A.; Casañas, A.; Roher, N.; Garcia, L.; Plana, M.; Gómez, N.; Itarte, E. Unbalanced activation of ERK1/2 and MEK1/2 in apigenin-induced HeLa cell death. Exp. Cell Res. 2004, 299, 15-26. [CrossRef] [PubMed]

36. Zhang, C.-L.; Wu, L.-J.; Zuo, H.-J.; Tashiro, S.-I.; Onodera, S.; Ikejima, T. Cytochrome c release from oridonin-treated apoptotic A375-S2 cells is dependent on p53 and extracellular signal-regulated kinase activation. J. Pharmacol. Sci. 2004, 96, 155-163. [CrossRef] [PubMed]

37. Xiao, D.; Singh, S.V. Phenethyl isothiocyanate-induced apoptosis in p53-deficient PC-3 human prostate cancer cell line is mediated by extracellular signal-regulated kinases. Cancer Res. 2002, 62, 3615-3619.

38. Lee, J.; John, T.; Steelman, L.S.; Chappell, W.H.; McCubrey, J.A. Akt inactivates ERK causing decreased response to chemotherapeutic drugs in advanced CaP cells. Cell Cycle 2008, 7, 631-636.

39. Oeckinghaus, A.; Ghosh, S. The NF-кB family of transcription factors and its regulation. Cold Spring Harb. Perspect. Biol. 2009, 1, a000034. [CrossRef]

40. Dan, H.C.; Adli, M.; Baldwin, A.S. Regulation of mammalian target of rapamycin activity in PTEN-inactive prostate cancer cells by IкB kinase $\alpha$. Cancer Res. 2007, 67, 6263-6269. [CrossRef]

41. Dan, H.C.; Cooper, M.J.; Cogswell, P.C.; Duncan, J.A.; Ting, J.P.-Y.; Baldwin, A.S. Akt-dependent regulation of NF-KB is controlled by mTOR and Raptor in association with IKK. Genes Dev. 2008, 22, 1490-1500. [CrossRef]

42. Xia, Y.; Shen, S.; Verma, I.M. NF-kappaB, an active player in human cancers. Cancer Immunol. Res. 2014, 2, 823-830. [CrossRef]

43. Huang, H.; Du, T.; Xu, G.; Lai, Y.; Fan, X.; Chen, X.; Li, W.; Yue, F.; Li, Q.; Liu, L.; et al. Matrine suppresses invasion of castration-resistant prostate cancer cells by downregulating MMP-2/9 via NF-kappa B signaling pathway. Int. J. Oncol. 2017, 50, 640-648. [CrossRef] [PubMed]

44. Zhang, J.; Shao, S.; Han, D.; Xu, Y.; Jiao, D.; Wu, J.; Yang, F.; Ge, Y.; Shi, S.; Li, Y.; et al. High mobility group box 1 promotes the epithelial-to-mesenchymal transition in prostate cancer PC3 cells via the RAGE/NF-kappaB signaling pathway. Int. J. Oncol. 2018, 53, 659-671. [CrossRef] [PubMed]

45. Ren, D.; Yang, Q.; Dai, Y.; Guo, W.; Du, H.; Song, L.; Peng, X. Oncogenic miR-210-3p promotes prostate cancer cell EMT and bone metastasis via NF-kappaB signaling pathway. Mol. Cancer 2017, 16, 117. [CrossRef] [PubMed]

46. Huang, S.; Wa, Q.; Pan, J.; Peng, X.; Ren, D.; Huang, Y.; Chen, X.; Tang, Y. Downregulation of miR-141-3p promotes bone metastasis via activating NF-kappaB signaling in prostate cancer. J. Exp. Clin. Cancer Res. 2017, 36, 173. [CrossRef]

47. Lu, Y.; Cai, Z.; Xiao, G.; Keller, E.T.; Mizokami, A.; Yao, Z.; Roodman, G.D.; Zhang, J. Monocyte chemotactic protein-1 mediates prostate cancer-induced bone resorption. Cancer Res. 2007, 67, 3646-3653. [CrossRef] 
48. Michalaki, V.; Syrigos, K.; Charles, P.; Waxman, J. Serum levels of IL-6 and TNF- $\alpha$ correlate with clinicopathological features and patient survival in patients with prostate cancer. Br. J. Cancer 2004, 90, 2312-2316. [CrossRef]

49. Schulze, J.; Weber, K.; Baranowsky, A.; Streichert, T.; Lange, T.; Spiro, A.S.; Albers, J.; Seitz, S.; Zustin, J.; Amling, M. p65-Dependent production of interleukin-1 $\beta$ by osteolytic prostate cancer cells causes an induction of chemokine expression in osteoblasts. Cancer Lett. 2012, 317, 106-113. [CrossRef]

50. Lu, Y.; Cai, Z.; Galson, D.L.; Xiao, G.; Liu, Y.; George, D.E.; Melhem, M.F.; Yao, Z.; Zhang, J. Monocyte chemotactic protein-1 (MCP-1) acts as a paracrine and autocrine factor for prostate cancer growth and invasion. Prostate 2006, 66, 1311-1318. [CrossRef]

51. Manning, B.D.; Toker, A. AKT/PKB Signaling: Navigating the Network. Cell 2017, 169, 381-405. [CrossRef]

Sample Availability: Samples of the compounds are not available from the authors.

(C) 2020 by the authors. Licensee MDPI, Basel, Switzerland. This article is an open access article distributed under the terms and conditions of the Creative Commons Attribution (CC BY) license (http://creativecommons.org/licenses/by/4.0/). 